\title{
Determinants of a Household's Choice of Drinking Water Source in Punjab, Pakistan
}

\author{
Sara Rauf', Khuda Bakhsh', Sarfraz Hassan', Abdul Majeed Nadeem³, \\ Muhammad Asif Kamran ${ }^{4}$ \\ 'Institute of Agricultural and Resource Economics, University of Agriculture, Faisalabad, Pakistan \\ ${ }^{2}$ COMSATS Institute of Information Technology Vehari, Pakistan \\ ${ }^{3}$ Department of Economics, Government College University, Faisalabad-Pakistan \\ ${ }^{4}$ Nuclear Institute for Agriculture and Biology, Faisalabad, Pakistan \\ Received: February 15, 2015 \\ Accepted: August 28, 2015
}

\begin{abstract}
The present study is designed to identify determinants of choice of drinking water supply by the households in Punjab province of Pakistan. The multinomial logit model is used for the analysis of choice of water source using the household integrated economic survey for 2010-11. Our findings suggest that family size and numbers of rooms in a dwelling have a strong effect on choice of drinking water source. Location of the respondents (rural/urban) is highly significant and has a positive effect on the choice of drinking water source, whereas mode of transportation has a significant effect but a negative relationship with ownership of hand and motor pumps.
\end{abstract}

Keywords: drinking water, water sources, water quality, environmental amenities

\section{Introduction}

Water in general and sources of drinking water in particular are critical factors ensuring sustainable development. High population growth rates coupled with climate change have caused enormous stress on water resources in developing countries [1]. Per capita water availability has decreased to critical levels and it is expected to decline substantially in the future. Issues of inequitable distribution across head and tail ends of canals and system losses make the situation worse. In such circumstances, a scarcity pricing system can address the issue while considering the optimal price inversely related to storage levels. This means increasing the price when demand is high and decreasing it in times of supply augmentation [2]. Poor-quality drinking water is another critical concern for policymakers as it is a host to different waterborne diseases in developing coun-

*e-mail: kbmultan@hotmail.com tries. Diarrhea is one of the major causes of death in developing countries. For a developing country like Pakistan every child faces four episodes of diarrhea in the early years of their lives. A quality water supply to households can change this situation [3].

Drinking water is obtained from heterogeneous sources including taps and hand-pumps (inside or outside house boundaries), open wells, ponds, etc. [4], and therefore the level of services - namely price, distance from source, quality, reliability, etc. - also vary depending on water source and access. A households' choice of drinking water depends on many factors, including time to reach the source, household size [4], education, awareness, electronic media [5-9], income [10], input prices, and taste [11].

Regarding quality water, only $65 \%$ of households have access to improved water sources in Pakistan [12]. Thus, a larger part of the population is exposed to unsafe and polluted drinking water [13]. Waterborne diseases resulting from poor-quality drinking water cause a financial burden 
on a households' budget. Households with no access to safe drinking water adopt different measures (e.g. bottled water) to access safe drinking water without confronting a financial burden. Households are willing to pay for an improved water supply system provided by the public sector, and a willingness to pay is significantly determined by awareness $[14,15]$, levels of education [16], social capital [17, 18], and household income [19].

Although a few studies have examined drinking water sources and their factors, these studies generally focus on nature, and on a single city only [3, 5, 9]. Considering the severity of drinking water issues and lack of systematic understanding of household choices for drinking water at the provincial level, there is a dire need to fill the information gap and provide scientific studies for policy makers. It is within this background that this study aims to assess household preferences for drinking water sources in Pakistani Punjab. It also examines factors affecting a household's choice of drinking water sources. This paper contributes to the literature on drinking water in Pakistan by evaluating the decision of households in choosing water sources using a multinomial logit model. Results of the study provide insight for policymakers for more accurately targeting initiatives that can result in better availability of quality drinking water to households.

\section{Materials and Methods}

\section{Source and Data}

Data used for this study are taken from the secondary source, i.e. the Household Integrated Economic Survey (HIES) for 2010-11. In this data set, a cross-section of 6,654 households were interviewed from the Punjab Province of Pakistan. Details of sample design and data collection methods can be obtained from the HIES Report 2010-11 [20].

Different sources of drinking water are reported by the households. Motor pumps are used by $42.2 \%$, followed by hand pumps $(24.2 \%)$, in-house tap $(22.7 \%)$, out-door taps $(4.6 \%)$, and water tankers $(2.4 \%)$. Other sources - including closed wells, open wells, unimproved sources, and mineral water - are used by $4 \%$ of total surveyed households.

\section{Analytical Method}

To examine the choice of water source, the multinomial logit (MNL) model is employed because the dependent variable for the study is of multi-categories with no natural ordering. This model allows comparison with a reference category to be applied for the unordered dependent variable, which is coded in dummy form. By using MNL, we examine the households' decisions for different drinking water sources. The unordered outcome variable $Y_{i j}^{*}$ is the $i^{\text {th }}$ household's utility if household i chooses water source $j$. If each household chooses the optimal water source for the highest satisfaction, the unordered or unobserved choice for the $i^{\text {th }}$ household for source $j$ can be expressed as follows:
Table 1. Summary statistic of the explanatory variables.

\begin{tabular}{|l|c|c|c|c|}
\hline \multicolumn{1}{|c|}{ Variable } & Mean & Std. Dev & Min & Max \\
\hline Residence (urban=1) & 0.42 & 0.49 & 0 & 1 \\
\hline Gender (male =1) & 0.88 & 0.32 & 0 & 1 \\
\hline Education (literate=1) & 0.59 & 0.49 & 0 & 1 \\
\hline Family Size & 6.19 & 2.76 & 1 & 32 \\
\hline $\begin{array}{l}\text { Distance (more than } \\
14 \text { minutes=1) }\end{array}$ & 3.03 & 0.17 & 0 & 1 \\
\hline $\begin{array}{l}\text { Transportation mean } \\
\text { (on foot=1) }\end{array}$ & 0.98 & 0.11 & 0 & 1 \\
\hline No. of rooms & 2.44 & 1.42 & 1 & 18 \\
\hline
\end{tabular}

$$
\begin{gathered}
Y_{i j}=1 \text { if } Y_{i j}^{*}>Y_{i k}^{*}, j \neq k \\
Y_{i j}=0 \text { if not } \\
Y_{i j}=Y\left(X_{i} \beta_{j}\right)+\varepsilon_{i j}
\end{gathered}
$$

...where $i=1,2, n$ indicating household while $j=1,2, m$ showing drinking water sources. We consider five categories of drinking water sources viz. inside taps, outdoor taps, hand pumps, motor pumps, and other water sources. In the above-given mathematical formulation, $\beta$ is a vector of parameters, and $\varepsilon_{i j}$ is the error term with zero mean and constant variance.

$X_{i}$ is the vector of explanatory variables. We considered seven explanatory variables, namely education of household head ( 1 for educated and 0 otherwise), gender ( 1 for male household head and 0 otherwise), distance between water source and residence ( 1 if it takes more than 14 minutes to reach the source and 0 otherwise), residence (dummy variable taking value of 1 if household lives in urban region and 0 otherwise), family size, number of rooms, and transportation mean used to take water from the source (it is equal to 1 if the household reaches the source by foot and 0 otherwise).

\section{Results and Discussion}

Before explaining econometrics results, we discuss summary statistics of variables. Table 1 shows that $42.2 \%$ of households reside in urban areas, whereas $57.8 \%$ of respondents are from the rural region. About $88 \%$ of heads of the households are male and they are commonly involved in all types of decisions, including drinking water sources. The literacy rate is very low in Pakistan and we find that only $59 \%$ of household heads are literate and this percentage is close to the national average. On average, family size is 6.2 , varying from 1 to 32 members. Considering the distance from the water source, $3 \%$ of the households report that it takes more than 14 minutes to reach water sources by foot. Those bringing water away from the house are above $98 \%$ and they have to reach water sources by foot. Furthermore, women are commonly 
Table 2. Results of multinomial logit regression for choice of drinking water sources.

\begin{tabular}{|c|c|c|c|c|}
\hline \multirow[b]{2}{*}{ Variables } & \multicolumn{4}{|c|}{ Drinking water sources } \\
\hline & $\begin{array}{l}\text { Inside } \\
\text { taps }\end{array}$ & $\begin{array}{c}\text { Outdoor } \\
\text { taps }\end{array}$ & $\begin{array}{l}\text { Hand } \\
\text { pump }\end{array}$ & $\begin{array}{c}\text { Other } \\
\text { sources }\end{array}$ \\
\hline \multirow{2}{*}{ Residences } & $0.86^{* * *}$ & $0.35^{* * *}$ & $-1.72 * * *$ & $0.76^{* * *}$ \\
\hline & $(0.07)$ & $(0.12)$ & $(0.09)$ & $(0.11)$ \\
\hline \multirow{2}{*}{ Gender } & 0.12 & 0.04 & $0.55^{* * *}$ & 0.24 \\
\hline & $(0.10)$ & $(0.18)$ & $(0.11)$ & $(0.18)$ \\
\hline \multirow{2}{*}{ Family Size } & $-0.03 * *$ & $-0.06 * *$ & 0.01 & $-0.07 * * *$ \\
\hline & $(0.01)$ & $(0.02)$ & $(0.01)$ & $(0.02)$ \\
\hline \multirow{2}{*}{ Distance } & -0.42 & $2.29 * * *$ & $0.93 * * *$ & $2.49 * * *$ \\
\hline & $(0.39)$ & $(0.23)$ & $(0.24)$ & $(0.25)$ \\
\hline \multirow{2}{*}{$\begin{array}{l}\text { No. of } \\
\text { rooms }\end{array}$} & -0.03 & $-0.14 * * *$ & $-0.47 * * *$ & $0.09 * * *$ \\
\hline & $(0.02)$ & $(0.05)$ & $(0.03)$ & $(0.03)$ \\
\hline \multirow{2}{*}{$\begin{array}{l}\text { Transportati } \\
\text { on Mean }\end{array}$} & $1.30^{*}$ & $-1.54 * * *$ & $-1.06 * *$ & $-1.17 * * *$ \\
\hline & $(0.77)$ & $(0.41)$ & $(0.41)$ & $(0.39)$ \\
\hline \multirow{2}{*}{ Education } & 0.11 & -0.18 & $-0.58 * * *$ & 0.03 \\
\hline & $(0.07)$ & $(0.13)$ & $(0.07)$ & $(0.12)$ \\
\hline $\begin{array}{l}\text { McFadden } \\
\text { R-Square }\end{array}$ & 0.11 & & & \\
\hline $\begin{array}{l}\text { LR Chi- } \\
\text { square (28) }\end{array}$ & $1,995.36^{* * *}$ & & & \\
\hline
\end{tabular}

Standard errors in parentheses.

$* * * \mathrm{p}<0.01, * * \mathrm{p}<0.05, * \mathrm{p}<0.1$

involved in taking water from the source to house and this increases the work burden. The number of rooms is used as a proxy variable for family wealth. This variable varies from 1 to 18 rooms in a house with a mean value of 2.44 rooms per household. However, this value is very small compared to the family size of the respondents.

\section{Results of the Econometric Model}

We are interested in examining determinants of a household's choice of drinking water sources. This is achieved by employing the MNL model and results are given in Table 2. We considered seven explanatory variables while taking motor pumps as the base source in the present study. Considering significance of the variables, some of the variables - namely, residence, family size, and transportation mode - are statistically different from zero for the inside water tap sources. For the outdoor water source, variables like residence, family size, distance, number of rooms, and transportation mode are significant variables. Residence, gender, distance, number of rooms, transportation mode, and education are found to be statistically significant factors affecting the choice of hand pumps. All variables except gender and education are statistically significant in the selection of the other sources.
Results in Table 2 show that if the respondent is from an urban region, the household has more access to inside taps, outdoor taps, and other sources as compared to rural areas. The urban residents are more likely to access inside taps as compared to motor pumps by 85.6 percentage points. Developing countries like Pakistan face challenges of quality drinking water due to rapid urbanization and industrialization. Jayalakshmi and Velappan [21] argue that around $76.5 \%$ of the total area in India is unfit for drinking. The situation is not different in Pakistan, where access to quality drinking water for households is a major challenge.

When the head of the household is male, there are more chances of water sources to be inside taps, outdoor taps, hand pumps, and other sources as compared to motor pumps. The marginal impact of the household head's level of education is only significant in one category, i.e. hand pump, but it is negative. Educated respondents have access to information regarding quality drinking water and such individuals are more cconcerned about the health impacts of using water derived from a hand pump or tap water. So education has a significant impact on a household's likelihood of drinking quality water, i.e. bottled water [22]. Further awareness regarding the presence of chemicals and micro-organisms in drinking water can increase sales of bottled water by $17 \%$ to $22 \%$ in order to avoid health costs [23].

The probability for inside taps, outdoor taps, hand pumps and other sources are likely to be less as compared to motor pumps if the family size is large. Contrary to Hindman [10], our study shows a positive impact on the choice of a household's water source, i.e. motor pumps. This can be due to the fact that a larger family size increases the demand for water and this increased demand can be fulfilled by the use of motor pumps. This result is in line with the study showing that the number of children is an important determinant of willingness to pay for quality drinking water [24]. With increased distance from the water source, the probability of using inside taps is less compared to motor pumps. It implies that when the source of water is far from the residence, a motor pump, etc. will be used by the household.

We also explored the effects of transportation means used to reach the water source. For the outdoor taps, hand pumps, etc., the probability of using these water sources decreases when the household member can reach the water source by foot in the absence of an alternate mode of transportation. This can be due to the fact that reaching the water source by foot is time-consuming and physically stressful or hectic, so its chance for selection as the main source of water decreases. We also estimate the effect of the number of rooms as a proxy variable for family wealth. It shows that households with a higher number of rooms are more probable to install motor pumps. The reason lies in the fact that wealthy households can afford a better source of water because of the association between wealth and access to quality water sources. Nauges and Strand [16] show wealth's impact on quality sources of drinking water. Households with rich wealth sources are health conscious and spend more on improved water resources used for 
drinking purposes [25, 26]. This signifies the importance of investing in infrastructure development for providing quality drinking water to households.

\section{Conclusions}

Safe drinking water is a basic human right and its provision guarantees better human health. This study helps us understand a household's choice for drinking water sources through empirical evidence. Family size is an important determinant as it is significantly related to the choice of drinking water source. Distance between water source and house is highly significant with a negative sign. Possession of more numbers of rooms (proxy for wealth) affects a household's decisions regarding selection of a drinking water source. Lack of transportation affects the choice of water source.

This study provided useful information for determining policy to improve safe drinking water supplies as households face different types of constraints in finding quality water sources. Sometimes people have to travel a long distance to fetch water for drinking purposes. Providing quality drinking water through public arrangement in the form of tap water can save households substantial time and energy, and this saved time can be used in other productive activities.

\section{References}

1. NAUGES C., WHITTINGTON D. Estimation of water demand in developing countries: An overview. World Bank Res. Obser. 25, (2), 263, 2010.

2. HUGHES N., HAFI A., GOESCH T. Urban water management: optimal price and investment policy under climate variability. Aust. J. Agr. Resour. Ec. 53, (2), 175, 2009.

3. KHAN H., IQBAL F., SAEED I., KHAN I. Estimating willingness to pay for improvements in drinking water quality: evidence from Peshawar, Northern Pakistan. Environ. Econ. 1, (2), 38, 2010.

4. MU X., WHITTINGTON D., BRISCOE J. Modelling village water demand behavior: a discrete choice-choice approach. Water Resour. Res. 26, 521, 1990.

5. KAUSAR S., MAANN A A., ZAFAR I., ALI T., KANWAL A. Household characteristics affecting drinking water quality and human health. Pak. J. Agr. Sci. 46, (3), 192, 2009.

6. FOTUE L. Awareness and the demand for improved drinking water source in Cameroon. Int. J. Econ. Prac. Theor. 3, (1), 50, 2013.

7. NAUGES C., VAN DEN BERG. Demand for piped and non-piped water supply services: Evidence from Southwest Sri Lanka. Environ. Res. Econ. 42, (4), 535, 2009.

8. FARZIN YH., GROGAN K.A. Socioeconomic factors and water quality in California. Environ. Econ. Policy Stud. 15, (1), 1, 2013.
9. AHMAD I., UL HAQ M., SATTAR A. Factors determining public demand for safe drinking water (A case study of district Peshawar). Pakistan Institute of Development Economics Working Paper 58, 2010.

10. KAUSAR S., ASGHAR K., ANWAR SM., SHAUKAT F., KAUSAR R. Factors affecting drinking water quality and human health at household level in Punjab, Pakistan. J. Life Soc. Sci., 9, (1), 33, 2011.

11. HIDMAN P.T. Household choice of drinking-water source in Philippines. Asian Econ. J. 16, (4), 303, 2007.

12. WORLD HEALTH ORGANIZATION (WHO). World Health Statistics 2008, World Health Organization, 20 Avenue Appia, 1211 Geneva 27, Switzerland, 2008.

13. MAHMOOD S., MAQBOOL A. Impacts of wastewater irrigation on water quality and on the health of local community in Faisalabad. Pak. J. Water Res. 10, 230, 2006.

14. JALAN J., SOMANATHAN E., CHAUDHURI S. Awareness and the demand for environmental quality: survey evidence on drinking water in urban India. Environ. Dev. Econ. 14, (6), 665, 2009.

15. KHAN NI., BROUWER R., YANG H. Household's willingness to pay for arsenic safe drinking water in Bangladesh. J. Environ. Manage. 143, (1), 151, 2014.

16. KWAK S.Y., YOO S.H., KIM C.S. Measuring the willingness to pay for tap water quality improvements: Results of a contingent valuation survey in Pusan. Water. 5, 1638, 2013.

17. NAUGES C., STRAND J. Estimation of non-tap water demand in Central American cities. Resour. Energy Econ. 29, 165, 2007.

18. POLYZOU E., JONES N., EVANGELINOS K.I., HALVADAKIS C.P. Willingness to pay for drinking water quality and the influence of social capital. The J. Socioecon. 40, (1), 74, 2011.

19. GENIUS M. Evaluating consumers' willingness to pay for improved potable water quality and quantity. Water Res. Manage. 22, 1825, 2008.

20. http://www.pbs.gov.pk/sites/default/files/pslm/publications/hies10_11/complete_report.pdf, Accessed August 2015.

21. JAYALAKSHMI S., VELAPPAN E. Assessment of water quality index in the St. Thomas Mount Block using GIS and remote sensing. Pol. J. Environ. Stud. 24, (4), 1611, 2015.

22. BONTEMPS C., NAUGES C. The impact of perception in averting-decision models: an application to the special regressor method to drinking water choices. Am. J. Agr. Econ. 2015. Advance access, doi. 10.1093/ajae/aav046

23. GRAFF ZJ., NEIDELL M., SCHLENKER W. Water quality violations and avoidance behavior: evidence from bottled water consumption. Am. Econ. Rev. 101, (3), 448, 2011.

24. BROX J.A., KUMAR R.C., STOLLERY K.R. Estimating Willingness to Pay for Improved Water Quality in the Presence of Item Nonresponse Bias. Am. J. Agr. Econ. 85, (2), 414, 2003.

25. SATTAR A., AHMAD E. HHs preferences for safe drinking water. Int. J. Human Dev. 3, (1), 23, 2007.

26. HAQ M., MUSTAFA U., AHMAD I. Household's willingness-to-pay for safe drinking water: A case study of district Abbottabad. The Pak. Dev. Rev. 46, (4), 1137, 2007. 